\title{
Forage production of reclaimed mined lands as influenced by nitrogen fertilization and mulching practice
}

\author{
G.E. SCHUMAN, E.M. TAYLOR, JR., AND F. RAUZI
}

\section{Abstract}

Fertilizer nitrogen (N) management and other cultural practices used in reciamation can have a significant effect on the successful revegetation of mined lands. Repeated fertilization of revegetated lands creates management and economic concerns. Nitrogen fertilizer was broadcast at $67 \mathrm{~kg} \mathrm{ha}^{-1} \mathrm{yr}^{-1}$ for 4 years and at $268 \mathrm{ha}^{-1}$ for 1 year on revegetated mined land to evaluate $\mathbf{N}$ management effects on forage production. Seeded grass production over 5 years did not exhibit consistent increases for the single $\mathbf{N}$ fertilizer application compared to the 4 annual applications. Although the single, higher N fertilization treatment only produced significantly greater forage in 3 instances compared to the lower annual fertilization treatment, it would result in a significant savings in application costs. Seeded grass production was higher and annual forb production lower when established using a standing grain stubble mulch compared to a crimped straw mulch. A single, higher application rate of nitrogen and a stubble mulch are recommended because of their production, management, and economic benefits.

Key Words: revegetation, stubble and crimped straw mulch, disturbed land treatment, nitrogen management

Authors are soil scientists and retired soil scientist, Agricultural Research Service, USDA, High Plains Grasslands Research Station, 8408 Hildreth Road, Cheyenne, Wyo. 82009 .

Manuscript accepted 16 September 1990.
Forage production of native grasslands in the Northern Great Plains is generally limited by water and nitrogen (N) (Smika et al. 1965, Power and Alessi 1971). Cultural practices such as irrigation, mulching and fertilization can play a significant role in the successful revegetation of mined lands. Nitrogen is often limiting in reconstructed soils following mining (Power et al. 1978). Low fertility of reconstructed soils can adversely affect plant establishment and long-term productivity of the revegetated community. Nitrogen fertilization has been shown to increase forage production of natural and reseeded grasslands (Power and Alessi 1971, DePuit et al. 1978). DePuit et al. (1978) found that $N$ fertilization can affect individual species and species interactions. Research has demonstrated the benefit of stubble mulch in seedling establishment (Schuman et al. 1980) and that the degree of success in stand establishment affected forage production in subsequent years (Ries et al. 1988).

The purpose of this research was to compare the effect of a single $\mathrm{N}$ fertilizer application (268 kg N ha ${ }^{-1}$ ) with that of 4 annual applications $\left(67 \mathrm{~kg} \mathrm{~N} \mathrm{ha}^{-1}\right.$ ) on forage production of a 2-year-old seeding established using crimped straw or stubble mulch techniques.

\section{Methods and Materials}

Field plots were established in the spring of 1977 at the PathJOURNAL OF RANGE MANAGEMENT 44(4), July 1991 
Table 1. Seeded grass, annual forb, and total production as affected by year, mulch practice, and $\mathrm{N}$ fertilizer management on reclaimed mined lands in Wyoming. Values are means of $20-0.18 \mathrm{~m}^{2}$ quadrats.

\begin{tabular}{|c|c|c|c|c|c|c|c|c|c|c|c|}
\hline \multirow[b]{3}{*}{$\begin{array}{l}\text { Production } \\
\text { component }\end{array}$} & \multirow[b]{3}{*}{$\begin{array}{l}\text { Mulch! } \\
\text { practice }\end{array}$} & \multicolumn{2}{|c|}{1979} & \multicolumn{2}{|c|}{1980} & \multicolumn{2}{|c|}{$\begin{array}{l}\text { Year } \\
1981\end{array}$} & \multicolumn{2}{|c|}{1982} & \multicolumn{2}{|c|}{1983} \\
\hline & & \multicolumn{10}{|c|}{$\overline{\text { Nitrogen Fertilizer Management }{ }^{2}}$} \\
\hline & & I & $\mathbf{A}$ & I & $\mathbf{A}$ & I & A & I & $\mathbf{A}$ & I & $\mathbf{A}$ \\
\hline & & & & & 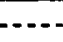 & --- & $-1-\ldots$ & $-\ldots$. & 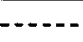 & 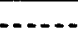 & ---- \\
\hline \multirow[t]{2}{*}{$\begin{array}{l}\text { Seeded } \\
\text { Grasses }\end{array}$} & $\begin{array}{l}\text { M1 } \\
\text { M2 }\end{array}$ & $\begin{array}{l}366 \\
489\end{array}$ & $\begin{array}{l}351 \\
461\end{array}$ & $\begin{array}{l}501 \\
568\end{array}$ & $\begin{array}{l}416 \\
591\end{array}$ & $\begin{array}{l}688 \\
760\end{array}$ & $\begin{array}{l}495 \\
865\end{array}$ & $\begin{array}{l}669 \\
905\end{array}$ & $\begin{array}{l}772 \\
707\end{array}$ & $\begin{array}{l}1100 \\
1012\end{array}$ & $\begin{array}{r}903 \\
1154\end{array}$ \\
\hline & \multicolumn{11}{|c|}{$\begin{array}{l}\text { LSD } 0.10=168(\mathrm{~N} \text { management within mulch and year); } 146 \text { (mulch practice within } \mathrm{N} \text { management and year); } 150 \text { (year within } \mathrm{N} \text { managemer } \\
\text { and mulch) }\end{array}$} \\
\hline \multirow[t]{2}{*}{$\begin{array}{l}\text { Annual } \\
\text { Forbs }\end{array}$} & $\begin{array}{l}\text { M1 } \\
\text { M2 }\end{array}$ & $\begin{array}{l}529 \\
288\end{array}$ & $\begin{array}{l}306 \\
298\end{array}$ & $\begin{array}{l}536 \\
373\end{array}$ & $\begin{array}{l}344 \\
242\end{array}$ & $\begin{array}{l}954 \\
946\end{array}$ & $\begin{array}{r}1196 \\
709\end{array}$ & $\begin{array}{l}367 \\
291\end{array}$ & $\begin{array}{l}439 \\
472\end{array}$ & $\begin{array}{l}623 \\
368\end{array}$ & $\begin{array}{l}670 \\
590\end{array}$ \\
\hline & \multicolumn{11}{|c|}{$\begin{array}{l}\mathrm{LSD}_{0.10}=164(\mathrm{~N} \text { management within mulch and year); } 155 \text { (mulch practice within } \mathrm{N} \text { management and year); } 159 \text { (year within } \mathrm{N} \text { managemen } \\
\text { and mulch) }\end{array}$} \\
\hline \multirow{3}{*}{ Total } & M1 & 895 & 656 & 1037 & 759 & 1642 & 1691 & 1036 & 1208 & 1723 & 1572 \\
\hline & M2 & 777 & 759 & 941 & 833 & 1707 & 1574 & 1196 & 1178 & 1381 & 1744 \\
\hline & \multicolumn{11}{|c|}{$\begin{array}{l}\mathrm{LSD}_{0.10}=142(\mathrm{~N} \text { management within mulch and year); } 141 \text { (mulch practice within } \mathrm{N} \text { management and year); } 149 \text { (year within } \mathrm{N} \text { managemen } \\
\text { and mulch) }\end{array}$} \\
\hline
\end{tabular}

$1 \mathrm{M} 1=$ crimped straw; $\mathrm{M} 2$ = standing grain stubble.

$2 \mathrm{I}=268 \mathrm{~kg} \mathrm{~N} \mathrm{ha}^{-1}$ single application; $\mathrm{A}=67 \mathrm{~kg} \mathrm{~N} \mathrm{ha}^{-1} \mathrm{yr}^{-1}$ (1979 through 1982).

finder Mines uranium mine near Shirley Basin in southcentral Wyoming. Elevation at the research site is $2,195 \mathrm{~m}$ and the average annual precipitation is $228 \mathrm{~mm}$ with $67 \%$ occurring during the growing season (April-August). The annual frost-free period averages 88 days.

Topsoil used in soil reconstruction was a Borollic Haplargid of the fine-loamy mixed family (Young and Singleton 1977) and was replaced at an average depth of $30 \mathrm{~cm}$ over regraded spoil. Overburden consisted of a $1-\mathrm{m}$ layer of White River geologic material over Wind River formation material. The reconstructed soil was deep-ripped to $45 \mathrm{~cm}$ on 60 -cm centers, disked, and then rollerharrowed for seedbed preparation. Ammonium-nitrate and treble super phosphate $(P)$ were each applied at $67 \mathrm{~kg} \mathrm{~N}$ or $P \mathrm{ha}^{-1}$. Twenty, 4.9- by 45.7-m plots were established on the treated area. A stubble mulch treatment was established on 10 randomly selected plots that were seeded to barley (Hordeum vulgare L.) in April 1977 at a rate of $50 \mathrm{~kg} \mathrm{ha}^{-1}$. The stubble mulch plots were mowed prior to seed maturation at $25-\mathrm{cm}$ height to prevent competition from volunteer barley plants the next year. The remaining 10 plots comprised the crimped straw mulch treatment and were fallowed during the 1977 growing season. The fallow plots were tilled with a V-sweep implement to control weed growth. No weeds were allowed to produce seed during the fallow period. In October 1977 all plots were seeded with a double-disk drill equipped with 1.25-cm depth bands. The plots were seeded to a mixture of western wheatgrass [ Pascopyrum smithii (Rybd.) A. Love], thickspike wheatgrass [Elymus lanceolatus (Scriber and J.G. Smith) Gould], slender wheatgrass [Elymus trachycaulus (Link) Gould ex Shinners], and green needlegrass [Stipa viridula Trin.]. The fallow plots were mulched with $5 \mathrm{Mg} \mathrm{ha}^{-1}$ of barley straw after seeding. The straw was hand-scattered to improve uniformity of distribution and crimped into the soil in 2 directions. Crimping the straw may have resulted in some seed burial to depths that restricted germination and emergence; however, the crimping process was carried out at about a $45-60^{\circ}$ angle to drilling direction to limit the potential for excess seed burial. The crimper consisted of vertical notched disks with spacings of $21 \mathrm{~cm}$; therefore, the total surface area affected was relatively small.

In the spring of 1979,5 stubble plots and 5 crimped straw plots were fertilized with a single $268 \mathrm{~kg} \mathrm{~N} \mathrm{ha}^{-1}$ application, and the other
5 stubble and crimped straw plots were fertilized at $67 \mathrm{~kg} \mathrm{~N} \mathrm{ha}^{-1}$. The plots which received the lower rate of nitrogen were fertilized with an additional $67 \mathrm{~kg} \mathrm{~N} \mathrm{ha}^{-1}$ in the spring of 1980,1981 , and 1982.

Forage production was determined by clipping to ground level all vegetation within 4 randomly located $0.18-\mathrm{m}^{2}$ quadrats within each plot from 1979 through 1983. Plant material was dried at $60^{\circ} \mathrm{C}$ for $24 \mathrm{hr}$ and weighed. Forage production was sampled when the majority of the species approached reproductive maturity.

Analysis of variance was used to determine significance of main effects and interactions, and mean separation was accomplished by least-significant-difference. All treatment effects were evaluated at the 0.10 level of probability.

\section{Results and Discussion}

Forage production (seeded grasses, forbs, and total) exhibited a significant $\mathbf{N}$ fertilizer management by mulch by year interaction (Table 1). Even though the 3-way interaction was significant, only a few of the specific mean comparisons were found to be significant. The lack of consistent significant responses to a given treatment or treatment combination is influenced by the high degree of variability in the data as evidenced by the large LSD values. However, some definite trends are evident in the data.

Seeded grasses produced more forage (60\% of the time) with the single $\mathbf{N}$ application compared to annual applications when evaluated over the 5 years. These differences were significant in 1981 and 1983 and in 1982 for the crimped straw and standing stubble mulch, respectively. The seeded grass production also showed a general increase over time with 1981,1982 , and 1983 production being significantly greater than that of 1979 and 1980 . The responses to the $\mathrm{N}$ and mulch observed from 1981 to 1983 were influenced and amplified by the greater precipitation received in those years (Table 2). The standing stubble mulch resulted in greater seeded grass production in $80 \%$ of the comparisons; however only half of the observed increases were significant. Greater seedling establishment in the stubble mulch plots compared to crimped straw plots was documented in 1978 when these plots were initially established (Schuman et al. 1980). They also reported significantly greater water infiltration on the stubble mulch treatment compared to the crimped straw mulch treatment. The small 
Table 2. Monthly precipitation during growing season, annual precipitation and average precipitation, Shirley Basin, Wyoming.

\begin{tabular}{lcccccc}
\hline \hline Year & April & May & $\begin{array}{c}\text { Month } \\
\text { June }\end{array}$ & July & August & Annual \\
\hline & - & & & & & \\
1978 & 42 & 69 & 20 & 24 & 29 & 266 \\
1979 & 9 & 14 & 12 & 20 & 20 & 157 \\
1980 & 4 & 54 & 2 & 18 & 30 & 167 \\
1981 & 12 & 92 & 4 & 51 & 13 & 243 \\
1982 & 10 & 39 & 51 & 70 & 21 & 257 \\
1983 & 24 & 24 & 57 & 57 & 20 & 279 \\
6-year & 17 & 49 & 24 & 40 & 22 & 228 \\
mean & & & & & & \\
\hline
\end{tabular}

grain crop used to establish the stubble mulch may have resulted in improved physical conditions of the revegetated soil, through root penetration, which led to the greater water infiltration (Schuman et al. 1980). In 1981-1983 the above-normal precipitation received may have resulted in greater water storage and $\mathrm{N}$ utilization in the stubble mulch treatment, which along with greater initial seedling establishment accounted for the greater forage production observed.

Annual forb production showed a rather random response to $\mathrm{N}$-fertilizer treatment. However, annual forb production was higher for the crimped straw treatment than for the stubble mulch treatment. Although $90 \%$ of the mulch treatment comparisons showed higher annual forb production for the crimped straw treatment, only $40 \%$ were statistically significant. The generally higher forb production observed for the crimped straw treatment is probably the result of less competition from seeded grasses because of the lower density achieved in 1978 during initial plant establishment (Schuman et al. 1980). Annual forb production peaked in 1981 for both N-fertilizer treatments and both mulch treatments and was significantly greater than for any other year. This large increase in annual forb production may have been partly in response to the $46 \%$ increase in precipitation over the previous 2 years and the nearly doubling of the May precipitation compared to the previous year and the 6-year average.

Total production was significantly greater in 1979,1980 , and 1983 for the single high $\mathrm{N}$-fertilizer treatment than for the lower annual application when using the crimped straw mulch; however, in 1982 this was reversed. Fertilizer treatment did not affect total production for the stubble mulch treatment except in 1983 when the single $\mathrm{N}$-fertilizer application produced significantly less than the annual fertilizer treatment. Mulch treatment had no significant effect on total production within a fertilizer treatment except in 1982 and 1983 when the stubble treatment exhibited significantly greater production in 2 instances and the crimped straw treatment showed greater production in 1983 when annual forb production was also significantly greater for that treatment. Total production was significantly greater in 1981, 1982, and 1983 than 1979 and 1980 for both fertilizer and both mulch treatments. This increased production can again be related to the greater precipitation received in those years.

Even though a significant fertilizer management by mulch treatment by year interaction occurred, few specific consistent trends in production could be shown. The 2 most important findings were: (1) seeded grass production was greater (in $60 \%$ of the cases) when fertilized with a single higher $\mathrm{N}$ application compared to annual applications with no difference shown in the remaining comparisons and (2) greater long-term seeded grass production was achieved on $80 \%$ of those plots established using the stubble mulch method even though the increased production was only statistically significant on half of those exhibiting the greater grass production. Schuman et al. (1980) and Ries et al. (1988) demonstrated that cultural practices (mulching and irrigation) resulting in greater seedling establishment will also result in greater production in subsequent years. The stubble mulch methods of seedbed preparation not only resulted in greater seedling establishment, but the cost is only a fraction of that for a crimped straw mulch (Schuman et al. 1980), and it continued to influence seeded grass production 7 years later. The stubble mulch treatment also exhibited less annual forb production compared to the crimped straw mulch treatment. Nitrogen fertilizer management had limited affect on seeded grass production, and where it did significantly influence production the single $\mathrm{N}$-application exhibited greater production than annual $\mathrm{N}$-applications. This finding indicates that a single large $\mathrm{N}$ fertilizer application can be used to ensure adequate fertility requirements of the revegetated community and avoid the expense of repeated annual $\mathrm{N}$ applications.

\section{Literature Cited}

DePuit, E.J., W.H. Willmuth, and J.G. Coenenberg. 1978. Research on revegetation of surface mined lands at Colstrip, Montana: Progress Report, 1975-1977. Montana Agr. Exp. Sta. Rep. 127.

Power, J.F. and J. Alessi. 1971. Nitrogen fertilization of semiarid grasslands: Plant growth and soil mineral N levels. Agron. J. 63:277-280.

Power, J.F., F.M. Sandoval, and R.E. Ries. 1978. Restoration of productivity to disturbed land in the Northern Great Plains. p. 33-49. In: R.A. Wright (ed.) The reclamation of disturbed arid lands, Univ. New Mexico Press, Albuquerque.

Ries, R.E., F.M. Sandoval, and J.F. Power. 1988. Irrigation water for vegetation establishment. J. Range Manage. 41:210-215.

Schuman, G.E., E.M. Taylor, Jr., F. Rauzi, and G.S. Howard. 1980. Standing stubble versus crimped straw mulch for establishing grass cover on mined lands. J. Soil \& Water Conserv. 35:25-27.

Smika, D.E., H.J. Haas, and J.F. Power. 1965. Effects of moisture and nitrogen on growth and water use by native grass. Agron. J. 57:483-486.

Young, J.F., and P.C. Singleton. 1977. Wyoming general soils map. Wyoming Agr. Exp. Sta. Res. J. 117. 